\title{
Evaluation of a Cooling Performance of a Typical Full Loaded Cool Storage Using Mono-scale CFD Simulation
}

\author{
Seyed Majid Sajadiye (Corresponding author) \\ Department of Mechanics of Agricultural Machinery, Faculty of Agricultural Engineering and Technology \\ University of Tehran, Karaj, Iran \\ Tel: 98-261-280-1011Ｅ-mail: mjdsjde@can.ut.ac.ir \\ Hojat Ahmadi \\ Department of Mechanics of Agricultural Machinery, Faculty of Agricultural Engineering and Technology \\ University of Tehran, Karaj, Iran \\ E-mail: hjahmadi@ut.ac.ir \\ Seyed Mostafa Hosseinalipour \\ Mechanical Engineering Department \\ Iran University of Science \& Technology, Tehran, Iran \\ E-mail: alipour@iust.ac.ir \\ Seyed Saeid Mohtasebi \\ Department of Mechanics of Agricultural Machinery, Faculty of Agricultural Engineering and Technology \\ University of Tehran, Karaj, Iran \\ E-mail: mohtaseb@ut.ac.ir \\ Mohammad Layeghi \\ Department of Wood \& Paper Science and Technology, Faculty of natural resources \\ University of Tehran, Karaj, Iran \\ E-mail: mlayeghi@ut.ac.ir \\ Younes Mostofi \\ Department of Horticultural Science, Faculty of Agricultural Science and Engineering \\ University of Tehran, Karaj, Iran \\ E-mail: ymostofi@ut.ac.ir \\ Amir Raja \\ Mechanical Engineering Department \\ Iran University of Science \& Technology, Tehran, Iran \\ E-mail: amir_raja@mecheng.iust.ac.ir \\ Received: May 16, $2011 \quad$ Accepted: November 10, $2011 \quad$ Published: January 1, 2012 \\ doi:10.5539/mas.v6n1p102 \\ URL: http://dx.doi.org/10.5539/mas.v6n1p102
}

\section{Abstract}

A mono-scale three-dimensional validated CFD model was developed to predict airflow, heat and mass transfer in order to evaluate the cooling performance of a typical full loaded cool storage. The bottom of the room was 
subjected to fresher and cooler air with relatively higher velocity, therefore the product's temperature reduced from top to bottom (at least from 288 to $286.21^{\circ} \mathrm{k}$ ) as well as from left to right (at least from 289.91 to $283.86^{\circ} \mathrm{k}$ ). The averaged absolute deviation of product's temperature varied versus cooling time and reached to the maximum of $2.1^{\circ} \mathrm{C}$ between the 7 and 9 th hours of cooling time and $0.7^{\circ} \mathrm{C}$ at the end of cooling process. Between 5.5 to $9.5^{\circ} \mathrm{C}$ difference was observed between the hottest and coolest product's temperature during the cooling time. The model predicted the average weight loss of $1.85 \%$ for apple during the six months period in cool storage.

Keywords: CFD model, Simulation, Cool storage, Cooling performance, Mono-scale, Airflow, Heat transfer, Mass transfer

\section{Introduction}

Freshness and quality of fruits and vegetables as well as products saleable weight depend on heat and moisture transfer rate during air-cooling in the cool storages. The heterogeneity of product temperature during the storage may causes either the fast deterioration due to the increased respiration at higher temperature or chilling injury at lower temperature. Since numerous design and operational parameters such as flow rate and configuration of cool air blowers, the arrangement of product containers, and physical properties of products would affect the cooling performance of the system, improving it may necessitate numerous experiments. Numerical simulation is usually an economic alternative to physical experiments, although it is imperative that the reliability of the model be established through validation against experimental data (Smale, et al., 2006). Computational fluid dynamics (CFD) models have been successfully applied for analyzing the effects of design and operational parameters on cooling characteristics of fruit and vegetables and good agreements between experiments and predicted results have been reported (Tassou and Xiang, 1998; Xu and Burfoot, 1999; Foster, 2002; Hoang, et al., 2000, 2003; Moureh, et al., 2002, 2009; Nahor, et al., 2005; Chourasia and Goswami, 2006, 2007; Delele, et al., 2009). Due to small dimensions of slots on the fruit container's wall and large dimension of cool storage enclosure, the Simulation of airflow, heat and mass transfer inside vented fruits containers stacked in a large industrial cool storage would be a challenge. Nahor et al. (2005) developed a CFD model of the airflow, heat and mass transfer in cool room. The walls of fruit packages considered to be perforated and due to high computational costs, only empty and partially loaded (with eight packages) were modeled. In the study carried out by Moureh et al. (2009), filled boxes were taken into account as a porous media, and a separated pressure drop was used for slotted box walls. Ferrua and Singh (2009) investigated different design parameters effective on cooling rate and homogeneity of strawberry packages. Due to small slots on the packages together with large domain, only a column of packages was simulated using symmetry boundary conditions. Delele et al. (2009) applied multi-scale CFD simulation for optimization in cool storage. In multi-scale simulation the knowledge from the detailed simulation of the fruit package is used to create a model of cool storage.

Mono-scale simulation with considering directly the slotted walls and the whole large physical domain of full loaded cool storage with no simplification assumptions could cause a very fine grid which increases computational costs. Considering the availability of more powerful computers, the purpose of this study was to evaluate the cooling performance of a full loaded cool storage by developing a mono-scale three-dimensional CFD model. The cooling performance of fruits and vegetables during cooling is evaluated based on the cooling rate and homogeneity of temperature inside the products (Ferrua and Singh, 2009). Predicted air velocity, product cooling rate and weight loss were validated against experiments by the same authors (submitted for publication) and good agreements between the simulations and experiments were reported.

\section{Materials and Methods}

\subsection{Cool Storage - The Simulation Domain}

Cool storage modeled in this study was based on the experimental conditions of the pilot cool storage of postharvest laboratory at Dept of Food Engineering and Post harvest Technology (Karaj, Iran) with the dimensions of $4 \mathrm{~m}$ length, $2.6 \mathrm{~m}$ width and $1.9 \mathrm{~m}$ height. The cooling unit was located at the top center of the storage and consisted of two axial fans of $0.25 \mathrm{~m}$ diameter for air circulation and a finned tube heat exchanger (Figure 1). Apples (Malus domestica Borkh cv. Golden Delicious) were packed in the vented containers of $30 \mathrm{~kg}$ weight. The wall slots were spread over the five faces of each container and allowed air to go through about $10 \%$ of the surface (Figure 2). The container's were made of high density polyethylene (HDPE) with $0.004 \mathrm{~m}$ thickness and the walls modeled as conducting walls. The bulk of apple in the containers was modeled as a porous media. The enclosure was loaded with 96 containers with the dimensions of $0.54 \mathrm{~m}$ length, $0.4 \mathrm{~m}$ width and $0.3 \mathrm{~m}$ height. The arrangement of apple containers is shown in Figure 1. Four containers stacked with a small vertical gap of $0.06 \mathrm{~m}$ and there were four stacks along Z-direction with $0.06 \mathrm{~m}$ horizontal gap. Six 
columns of stacks $\mathrm{C} 1$ to $\mathrm{C} 6$ positioned alongside X-direction with $0.1 \mathrm{~m}$ horizontal gap. All the gaps between the container and room's sidewalls were $0.1 \mathrm{~m}$. The distance between containers and roof, bottom, back and front walls of room considered as $0.46,0.1,0.85$ and $0.25 \mathrm{~m}$; respectively, considering Guidelines of settings in a refrigerated warehouse (IIR, 1966; Woolrich and Hallowell, 1970).

\subsection{Governing Equations}

\subsubsection{Continuity and Momentum Equations}

The following are the governing equations in the turbulent flow regime inside the cool storage as well as fans, heat exchanger and containers of apples (Anonymous, 2003). Equations are expressed in Cartesian coordinate system.

$$
\begin{aligned}
& \frac{\partial \rho}{\partial t}+\frac{\partial}{\partial x i}(\rho m a u i)=0
\end{aligned}
$$

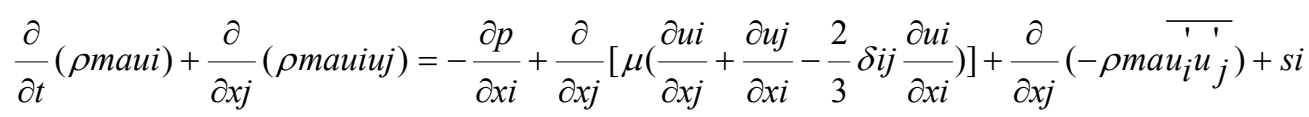

The standard k- $\varepsilon$ turbulence model was applied in the model in which the specific Reynolds stress term $\overline{u_{i} u_{j}^{\prime}}$ was approximated as follows (Veorsteeg and Malalasekera, 1995):

$$
\overline{u_{i}^{\prime} u_{j}^{\prime}}=-\frac{u t}{\rho m a}\left(\frac{\partial u i}{\partial x j}+\frac{\partial u j}{\partial x i}\right)+\frac{2}{3} k \delta i j
$$

Bulk of apple inside the containers was considered as porous media by adding momentum source term to the standard fluid flow equations. The source term is composed of two terms: viscous and inertial loss terms. This momentum source contributed to the pressure gradient in porous cells, creating a pressure drop that is proportional to the fluid velocity in the cells and was calculated using the following equation (Anonymous, 2003):

$$
s_{i}^{p}=-\left(\frac{\mu}{\alpha} u i+\frac{1}{2} \operatorname{coma}|u| u i\right)
$$

To take in to account the effect of confining walls on the viscose and inertial resistance of the porous zone, Eisfeld and Schnitzlein (2001) modified the correlation of Reichelt (1972) for confined beds, with the following coefficients for Eq. (4):

$$
\begin{aligned}
& \frac{1}{\alpha}=\frac{K 1 A_{W}^{2}(1-\gamma)^{2}}{d_{p e}^{2} \gamma^{3}} \\
& c=\frac{2 A_{W}(1-\gamma)}{B_{W} d_{p e} \gamma^{3}}
\end{aligned}
$$

Where the apple equivalent diameter $\left(d_{p e}=\left({ }^{6} V_{P} / \pi\right)^{\frac{1}{3}}\right)$ was estimated using Gaskell (1992). $A_{w}$ and $B_{w}$ are analytical expressions for considering the effect of the confining walls can be found in Reichelt (1972).

Fan and heat exchanger acted as a source of momentum. The heat exchanger resistance which introduced by Zukauskas and Ulinskas (1983) applied as a momentum source:

$$
\Delta p=-C m z \rho \frac{\alpha^{2}}{2(\alpha-1)^{2}}|u| u x
$$


Where $\Delta p$ is the pressure drop due to the resistance of the cooler tubes; $\mathrm{C}$ is a constant factor and is equal to $0.3 ; \mathrm{z}$ is the number of tube rows; $\mathrm{m}$ is a geometry parameter estimated using:

$$
m=1.004(a-1 / b-1)^{-0.539} \text { where } a=D_{1} / D_{h} ; b=D_{2} / D_{h} . \text { Here, } D_{h} \text { is the diameter of the tube; } \mathrm{D}_{1} \text { and } \mathrm{D}_{2}
$$

are transversal and longitudinal pitch of the tubes; respectively. The fan model was formulated based on the fan characteristic provided by the supplier: $\Delta p=C 1+C 2|u|+C 3|u| u s$, where $\mathrm{C} 1, \mathrm{C} 2$ and $\mathrm{C} 3$ are experimental coefficients, obtained from the characteristic curve and was equal to 95.97, -26.24 and 1.738; respectively.

\subsubsection{Species transport equation}

The variations of water vapor mass fraction in the enclosure during the cooling time were used to estimate the weight loss of the products. The conservation equations for chemical species of water vapor used in the model as follow (Anonymous, 2003):

$$
\frac{\partial}{\partial t}(\rho m a Y W)+\nabla \cdot\left(\rho m a \vec{v} Y_{W}\right)=-\nabla \cdot \overrightarrow{J_{W}}+S_{W}
$$

where $J_{W}$ is the diffusion flux of species water vapor, which arises due to concentration gradients and can be calculated for turbulent flow as: $\overrightarrow{J_{W}}=-(\rho m a D+\mu / S c t) \nabla Y_{W}$ where $(S c t)$ is the turbulent Schmidt number $\left(S c t=\mu_{t} / \rho m a D_{t}\right), \mu_{t}$ is the turbulent viscosity and $D_{t}$ is the turbulent diffusivity. $S_{W}$ is the rate of the water vapor production per unit volume of products and can be estimated using: $S_{W}=m A s$. Transpiration rate per unit area of product surface $(\dot{m})$ was calculated using a lumped model, neglecting the moisture diffusion inside the products and assuming a local equilibrium at the product surface and could be expressed as (Chourasia and Goswami, 2007; Delele, et al., 2009):

$$
\dot{m}=h m(P v p-P v a)
$$

where vapor pressure at product surface $\left(\mathrm{p}_{\mathrm{vp}}\right)$ and vapor pressure of ambient moist air $\left(\mathrm{p}_{\mathrm{va}}\right)$ were estimated using: $P v p=a_{w} P s a t ; \quad P v a=P s a t(R H / 100)$. Mass transfer coefficient in bulk of product $\left(\mathrm{h}_{\mathrm{m}}\right)$ consists of resistance of the apple skin mass transfer coefficient $\left(\mathrm{h}_{\mathrm{s}}\right)$ and the air film mass transfer coefficient $\left(\mathrm{h}_{\mathrm{a}}\right)$ and was estimated using : $1 / h_{m}=1 / h_{s}+1 / h_{a}$ (Delele, et al., 2009). The skin mass transfer coefficient for apple was considered $0.167 \times 10^{-9} \mathrm{~kg} \mathrm{~m}^{-2} \mathrm{~s}^{-1} \mathrm{~Pa}^{-1}$ (Chau, et al., 1987) and the air film mass transfer coefficient was estimated using Sherwood-Reynolds-Schmidt correlation (Chau et al., 1987):

$$
S h=2+0.552 \operatorname{Re}^{0.53} S c^{0.33}
$$

where (Sh) is Sherwood number $\left(S h=R_{H 2} O_{m a}\right.$ hadpe $\left./ D\right),(\mathrm{Re})$ is Reynolds number $(\operatorname{Re}=$ us $\rho m a d p e / \gamma \mu m a)$ and $(\mathrm{Sc})$ is Schmidt number $(S c=v / D)$. In different superficial velocities between 0.001 to $0.1 \mathrm{~m} \mathrm{~s}^{-1}$, the air film mass transfer coefficient was much more than skin mass transfer coefficients. Therefore, the overall mass transfer coefficient would be almost equal to skin mass transfer coefficient. 


\subsubsection{Energy Equations}

Assuming a local thermal equilibrium between the air and the porous solid inside the containers, the governing energy equation for porous media was (Nakayama and Kuwahara, 2005):

$$
\frac{\partial}{\partial t}\left(\gamma \rho m a E m a+(1-\gamma) \rho S E S+\nabla \cdot(\vec{u}(\rho m a E m a+p))=\nabla \cdot\left(k e f f \nabla T-\sum_{j} h_{j} \overrightarrow{J_{j}}+(\overline{\overline{\tau e f f}} \cdot \vec{u})\right)+S_{h}\right.
$$

Where the effective thermal conductivity of the bulk ( $\left.\mathrm{k}_{\mathrm{eff}}\right)$ estimated using: $k_{e f f}=\gamma k_{m a}+(1-\gamma) k_{p}$ where $k_{m a}$ and $k_{p}$ are moist air and products conductivity; respectively. For the containers, the source term $\mathrm{S}_{\mathrm{h}}$ took into account of metabolic rate of heat generation during respiration as well as evaporative cooling due to moisture loss during the transpiration and was calculated as the following:

$$
S_{k}^{p}(\rho b u l k q p)-(\dot{m} A s h i)
$$

where the rate of respiratory heat generation per unit mass of product $\left(\mathrm{q}_{\mathrm{p}}\right)$ calculated using USDA reported correlation (USDA, 1986): $q_{p}=\rho b u l k f(1.8 T-459.67)^{\mathrm{g}}, \mathrm{f}$ and $\mathrm{g}$ were: $1.69 \times 10^{-6}$ and 2.59; respectively (USDA, 1986).

The energy equation for the air inside the cool storage had the following form:

$$
\frac{\partial}{\partial t}(\rho E)+\nabla \cdot(\vec{u}(\rho E+p))=\nabla \cdot\left(k e f f \nabla T-\sum_{j} h_{j} \overrightarrow{J_{j}}+(\overline{\overline{\tau e f f}} \cdot \vec{u})\right)+S_{h}
$$

A lumped model was used to describe the heat exchange inside the heat exchanger. Convection exchanges were assumed to follow Newton's law of heat transfer. At the cooler, the heat was removed from the air and was calculated by the following expression:

$$
S_{h}^{c}=-\frac{h_{h} A_{h}\left(T m a-T_{h}\right)}{V_{h}}
$$

where surface heat transfer coefficient at finned tube heat exchanger $\left(h_{h}\right)$ was estimated using heat exchanger j and JP factors reported by McQuiston (1981) for finned tube heat exchanger: $j=\left(h / G_{h^{c} \text { pma }}\right) \operatorname{Pr}^{2 / 3}=0.00125+0.27 J P ; \quad J P=\operatorname{Re}_{D}^{0.4}\left(A 0 / A_{h}\right)^{-0.15}$, where $\mathrm{G}_{\mathrm{h}}$ is mass velocity at minimum flow area of heat exchanger $\left(G_{h}=60 \rho_{m a} v_{\min }\right)$ and $\mathrm{Re}_{\mathrm{D}}$ is Reynolds number based on tube diameter $\left(\operatorname{Re}_{D}=G_{h} D_{h} / \gamma \mu_{m a}\right)$.

\subsection{Boundary Conditions}

Since the fluid flow and domain geometry have symmetry along X-direction, only one-half of the domain was simulated. A lumped model was considered for fan boundary condition to predict the amount of flow. However, it did not consider the turbulence due to fan blades. Apples inside containers considered to behave as a porous media and generate heat through respiration and lose moisture due to the vapor pressure deficit. The walls of containers supposed to be conducting wall. No-slip boundary conditions and zero heat flux were considered as the appropriate boundary conditions at the walls of cool storage. Standard wall functions approach was used to avoid very fine grid near the solid walls (Anonymous, 2003).

\subsection{Properties and Model Parameters}

All the parameters related to the apple, fan and heat exchanger were extracted from several measurements or different references, shown in Table 1. True density, bulk density, porosity, moisture content and surface area of 100 apples samples were measured in order to calculate other parameters. Bulk specific area was estimated from the correlation developed by Dullien (1979). Apple thermo-physical properties were extracted from correlations developed by USDA (1986) based on the apple moisture content. Moist air properties extracted using 
psychometric table developed by ASHRAE (1993). Fan parameters obtained from the manufacturer pressure-flow curve. Heat exchanger parameters were obtained from measurements and also using correlation developed by McQuiston (1981). Apple bulk viscose and inertial resistances were extracted from correlation developed by Reichelt (1972) and Gaskell (1992).

\subsection{Solution Procedure and Numerical Method}

The model geometry and grid were created using preprocessor Gambit v.2.3.16 software. After comparing three different grid resolution results and considering the CPU time of each calculation, a uniform tetrahedral mesh size of $0.02 \mathrm{~m}$ for the entire domain was selected. The grid then refined near the walls to satisfy the standard wall function conditions to bound y between 30 and 300 . The refinements were done gradually to avoid large errors, which could be occurred in the calculation when adjacent cell size changes more than $50 \%$. The total numbers of cells was about 2150000 (Figure 3). A finite volume code was used for the numerical implementation of the models. Standard k- $\varepsilon$ turbulence model was enabled based on the previous studies (Nahor, et al., 2008). The overall accuracy of the model was selected as second order upwind. The pressure-velocity coupling was ensured using SIMPLE algorithm. Prior to enabling heat and species transport and porous zone properties, the model was solved for velocity field, using small time step $0.1 \mathrm{~s}$ by unsteady solver applying four parallel processors. Then, time steps gradually increased up to 10 seconds. After overall flow time of 300 seconds, porous zones, heat and species transport and user defined functions for heat exchanger, heat generation and moisture loss of apples enabled in the solver. Initial temperature of $25^{\circ} \mathrm{C}$ and initial zero mass fraction for vapor, patched to the entire of the domain. Convergence criteria set to absolute value of residuals $10^{-3}$ for continuity, velocity, $\mathrm{k}, \varepsilon$ and vapor mass faction, and $10^{-6}$ for energy equation. Then, the time steps increased up to $100 \mathrm{~s}$ and data files were auto saved after each time step. Calculations were done using a Windows XP work station with Intel Core TM 2 Quad $2.83 \mathrm{GHz}$ CPU and 3.25GB of RAM. A total CPU time of about $230 \mathrm{hrs}$ were needed to simulate $24 \mathrm{hrs}$ of real cooling process.

\section{Results and Discussion}

\subsection{Air Velocity Distributions}

The general flow pattern is illustrated in Figure 4. The airflow leaving the fan accelerates along X-direction and then reaches the ceiling and detours to the front wall then flows downward and returns to the cooling unit through the containers with a little more velocity close the floor. The flow pattern through the containers on the surface, crossing the center of the fan plan, and topmost and bottommost containers are shown in Figures 5 and 6; respectively. Most of the flow was passing through the vertical gaps. Little flow passed through the horizontal gaps especially at the bottom. The air velocity close to the sidewall of cool storage is relatively more. More uniform direction velocity vectors are seen on the bottom in comparison with top containers. This is due to the closeness of the fan and the effects of air jet to the top containers.

Average velocity magnitude inside the six columns and four rows of containers is shown in Figure 7. It could be observed that the averaged velocity increased from 0.0077 to $0.0307 \mathrm{~m} \mathrm{~s}^{-1}$ (about $300 \%$ increases) from left to right in columns of containers. The similar result with less intensity was observed inside the rows where the averaged velocity magnitude increased from 0.0154 to $0.0195 \mathrm{~m} \mathrm{~s}^{-1}$ (about $25 \%$ increases) from top to bottom in rows. The maximum, minimum, average and averaged absolute deviations of predicted volume averaged velocity magnitude inside the containers were predicted $0.0408,0.0047,0.016$ and $0.0065 \mathrm{~m} \mathrm{~s}^{-1}$ respectively. The average velocity magnitude predicted for the free space of cool storage enclosure was predicted $0.526 \mathrm{~m} \mathrm{~s}^{-1}$.

\subsection{Cooling Rate}

The cooling curves for the hottest and coolest container's temperature are presented in Figure 8 and compared with the cooling curves of all containers (based on the average temperature of all containers) and averaged air temperature of cool storage. The temperature of coolest container is less than the air temperature because of the evaporation heat loss of products.

Figure 9 shows predicted product temperature after $8.7 \mathrm{hrs}$ of cooling (half cooling time: time necessary to reduce the temperature difference between initial and set point temperature by a half) from an initial uniform temperature of $25^{\circ} \mathrm{C}$. About $9.5^{\circ} \mathrm{C}$ difference was observed between the hottest and coldest product temperature at half cooling time. This difference changes during the cooling time (Figure 10) and reaches to about $5.5^{\circ} \mathrm{C}$ at the end of the cooling period when the average product temperature reached to ideal maintaining temperature for apple $\left(0^{\circ} \mathrm{C}\right)$. The product's temperature heterogeneity can be calculated as the averaged absolute deviations of 
temperature $\left(T_{A V E D E V}=\frac{1}{n} \sum\left|T_{a v e}-T_{c}\right|\right)$ inside the cool storage. The averaged absolute deviations of temperature versus time of cooling is shown in Figure 10. The maximum of product's temperature heterogeneity was predicted $2.1^{\circ} \mathrm{C}$ between the 7 and 9 hours of cooling and reduced to $0.7^{\circ} \mathrm{C}$ at the end of the cooling.

Averaged product temperature of the six columns and four rows of containers at half cooling time is shown in Figure 11. It could be observed that the average product temperature decreased from 289.91 to $283.86^{\circ} \mathrm{k}$ (about $6^{\circ} \mathrm{k}$ ) from left to right in columns. The similar result with less intensity was observed in rows where the average product temperature decreased from 288 to $286.21^{\circ} \mathrm{k}$ (about $2^{\circ} \mathrm{k}$ ) from top to bottom in rows. The bottom of the room was subjected to the fresher and cooler air with relatively higher velocity (Figure 5) that is why the product temperature reduced from top to bottom and from left to right.

\subsection{Weight Loss}

Average of predicted vapor mass fraction during the cooling time can be used to estimate the weight loss of the products. Due to a large computational costs needed for each simulation, the weight loss of the product after a long times can be estimated by extrapolation based on the weight loss rate at the end of the cooling process, when the product temperature attained the steady state condition. After the steady conditions, the rate of moisture transferred from the products to the air is more affected by skin mass transfer coefficient than air film mass transfer coefficient; therefore, the difference in air velocity inside the bulk of the apple in containers did not show large difference in moisture loss. The result showed the average weight loss of $0.102 \mathrm{gr} \mathrm{H}_{2} \mathrm{O}$ per $\mathrm{kg}$ apple during $24 \mathrm{hrs}$ which is equal to $1.85 \%$ weight loss by extrapolation to 6 months.

\section{Conclusion}

A mono-scale three-dimensional validated CFD model was developed to simulate airflow, heat and mass transfer in a typical full loaded cool storage. Dynamic behavior of the fan, heat exchanger as well as respiration and transpiration of apple were considered in the model. A very fine grid was generated for slot ventilated walls of apple containers as well as the entire of the large domain of the cool storage. Airflow pattern and cooling curves of products was investigated. The numerical results were used to evaluate the cooling rate and temperature heterogeneity inside the cool storage. The results showed that the average velocity inside the containers increased from 0.0077 to $0.0307 \mathrm{~m} \mathrm{~s}^{-1}$ (about 300\% increased ) along X-direction from left to right The similar results with less intensity were observed from top to bottom along Y-direction where velocity magnitude increased from 0.0154 to $0.0195 \mathrm{~m} \mathrm{~s}^{-1}$ (about $25 \%$ increased). The bottom of the room was subjected to fresher and cooler air with relatively higher velocity, therefore the product's temperature reduced from top to bottom (at least from 288 to $286.21^{\circ} \mathrm{k}$ at half cooling time) as well as from left to right (at least from 289.91 to $283.86^{\circ} \mathrm{k}$ at half cooling time). The averaged absolute deviation of product's temperature (product's temperature heterogeneity) varied versus cooling time and reached to maximum about $2.1^{\circ} \mathrm{C}$ between the 7 and 9 th hours of cooling time. At the end of the cooling, the product's temperature heterogeneity reduced to $0.7^{\circ} \mathrm{C}$. Between 5.5 to $9.5^{\circ} \mathrm{C}$ difference was observed between the hottest and coolest product's temperature during the cooling time. The model predicted the average weight loss of $1.85 \%$ for apple during the six months period in cool storage.

\section{Acknowledgement}

The authors would like to thank staff members of CFD and CAE Lab center of Mechanical Engineering Department, Iran University of Science \& Technology (Tehran, Iran), and staff members of Postharvest Lab of Department of Horticultural science in University of Tehran for their helps, Dr. J. Moureh for providing several valuable papers and finally university of Tehran for financial support of the project.

\section{References}

Anonymous. (2003). FLUENT 6.1 User's Guide. Lebanon, NH: Fluent, Inc.

ASHRAE. (1993). ASHRAE Handbook of Fundamentals. Atlanta: American Society of Heating, Air Conditioning, and Refrigerating Engineers, Inc.

Chau, K. V., Romero, R. A., Baird, C. D., \& Gaffney, J. J. (1987). Transpiration coefficient of fruit and vegetables in refrigeration storage. Atlanta: American Society of Heating, Air Conditioning, and Refrigerating Engineers, Inc., (report 370-RP).

Chourasia, M. K., \& Goswami, T. K. (2006). CFD Simulation of Transport Phenomena during Natural Convection Cooling of Bagged Potatoes in Cold Storage, Part I: Fluid Flow and Heat Transfer. Biosystems Engineering, 94(1), 33-45. http://dx.doi.org/10.1016/j.biosystemseng.2006.02.003 
Chourasia, M. K., \& Goswami, T. K. (2007). CFD simulation of effects of operating parameters and product on heat transfer and moisture loss in the stack of bagged potatoes. Journal of Food Engineering, 80(3), 947-960. http://dx.doi.org/10.1016/j.jfoodeng.2006.07.015

Delele, M. A., Schenk, A., Tijskens, E., Ramon, H., Nicolaï, B. M., \& Verboven, P. (2009). Optimization of the humidification of cold stores by pressurized water atomizers based on a multi-scale CFD model. Journal of Food Engineering, 91, 228-239. http://dx.doi.org/10.1016/j.jfoodeng.2008.08.027

Dullien, F. A. L. (1979). Porous media: Fluid transport and pore structure. New York: Academic Press.

Eisfeld, B., \& Schnitzlein, K. (2001). The influence of confining walls on the pressure drop in packed beds. Chemical Engineering Science, 56, 4321-4329. http://dx.doi.org/10.1016/S0009-2509(00)00533-9

Ferrua, M. J., Singh, R. P. (2009). Design guidelines for the forced-air cooling process of strawberries. International Journal of Refrigeration, 32(8), 1932-1943. http://dx.doi.org/10.1016/j.ijrefrig.2009.07.011

Foster, A. M., Barrett, R., James, S. J., \& Swain, M. J. (2002). Measurement and prediction of air movement through doorways in refrigerated rooms. International Journal of Refrigeration, 25, 1102-1109. http://dx.doi.org/10.1016/S0140-7007(01)00108-6

Gaskell, D. R. (1992). An Introduction to Transport Phenomena in Materials Engineering. New York: Macmillan Publishing Company.

Hoang, M. L., Verboven, P., Baelmans, M., \& Nicolaï, B. M. (2003). A continuum model for airflow, heat and mass transfer in bulk of chicory roots. Transactions of the ASAE, 46 (6), 1603-1611.

Hoang, M. L., Verboven, P., De Baerdemaeker, J., \& Nicolaï, B. M. (2000). Analysis of airflow in a cold store by means of computational fluid dynamics. International Journal of Refrigeration, 23, 127-140. http://dx.doi.org/10.1016/S0140-7007(99)00043-2

IIR (1966). Practical Guide to Refrigerated Storage. Oxford: Pergamon Press.

McQuiston, F. C. (1981). Fined tube heat exchangers: state of the art for the air side. ASHRAE transaction, 87, 1077-1085.

Moureh, J., Menia, N., \& Flick, D. (2002). Numerical and experimental study of airflow in a typical refrigeration truck configuration loaded with pallets. Computers and Electronics in Agriculture, 34, 25-42. http://dx.doi.org/10.1016/S0168-1699(01)00178-8

Moureh, J., Tapsoba, S., Derensa, E., \& Flick, D. (2009). Air velocity characteristics within vented pallets loaded in a refrigerated vehicle with and without air ducts. International Journal of Refrigeration, 32, 220-234. http://dx.doi.org/10.1016/j.jirefrig.2008.06.006

Nahor, H. B., Hoang, M. L., Verboven, P., Baelmans, M., \& Nicolaï, B. M. (2005). CFD model of the airflow, heat and mass transfer in cooling stores. International Journal of Refrigeration, 28, 368-380. http://dx.doi.org/10.1016/j.ijrefrig.2004.08.014

Nakayama, A., \& Kuwahara, F. (2005). Algebraic model for thermal dispersion heat flux within porous media. AIChE Journal, 51(10), 2859-2864. http://dx.doi.org/10.1002/aic.10503

Reichelt, W. (1972). Zur Berechnung des Druckverlustes einphasig durchstr.omter Kugel-und Zylindersch.uttungen. [On the calculation of the pressure loss of one-phase flow through stacks of spheres and cylinders]. Chemie-Ingenieur- Technik, 44, 1068-1071.

Tassou, S. A., \& Xiang, W. (1998). Modelling the environment within a wet air-cooled vegetable store. Journal of Food Engineering, 38, 169-187. http://dx.doi.org/10.1016/S0260-8774(98)00117-4

USDA (1986). USDA agricultural handbook: number 66. United States Department of Agriculture.

Veorsteeg, H. K., Malalasekera, W. (1995). An Introduction to Computational Fluid Dynamics-The Finite Volume Method. New York: John Wiley and Sons.

Verboven, P., Hoang, M. L., Baelmans, M., \& Nicolaï, B. M. (2004). Airflow through Beds of Apples and Chicory Roots. Biosystems Engineering, 88(1), 117-125. http://dx.doi.org/10.1016/j.biosystemseng.2004.02.002

Woolrich, W. R., Hallowell, E. R. (1970). Cold and Freezer Storage Manual. Westport, CT: AVI Publishing Co.

Xu, Y., \& Burfoot, D. (1999). Simulating the bulk storage of food stuffs. Journal of Food Engineering, 39, 23-29. http://dx.doi.org/10.1016/S0260-8774(98)00139-3 
Zukauskas, A., \& Ulinskas, R. (1983). Banks of plain and finned tubes. In G.F. Hewitt (Ed.). Heat exchanger design Handbook. Washington, D. C.: Hemisphere publishing corp.

\section{Nomenclature}

$\mathrm{A}_{\mathrm{o}}$

$\mathrm{A}_{\mathrm{s}}$

$a_{w}$

$\mathrm{A}_{\mathrm{w}} ; \mathrm{B}_{\mathrm{w}}$

$\mathrm{C}$

$\mathrm{c}_{\mathrm{pma}}$

D

$\mathrm{D}_{\mathrm{h}}$

$\mathrm{d}_{\mathrm{pe}}$

E

$\mathrm{E}_{\mathrm{r}}$

$\mathrm{G}_{\mathrm{h}}$

$\mathrm{h}_{\mathrm{a}}$

$\mathrm{h}_{\mathrm{h}}$

$\mathrm{h}_{\mathrm{J}}$

$\mathrm{h}_{1}$

$\mathrm{h}_{\mathrm{m}}$

$\mathrm{h}_{\mathrm{s}}$

j, JP

$\mathrm{J}_{\mathrm{J}}$

-

m

$\mathrm{k}$

$\mathrm{k}_{\text {eff }}$

$\mathrm{K}_{1}, \mathrm{k}_{1}, \mathrm{k}_{2}$

$\mathrm{p}$

Pr

$\mathrm{p}_{\text {sat }}$

$\mathrm{P}_{\text {va }}$

$\mathrm{P}_{\mathrm{vp}}$

$\mathrm{q}_{\mathrm{p}}$

Re

$\mathrm{R}_{\mathrm{H} 2 \mathrm{O}}$

$\mathrm{RH}$

$\mathrm{Sc}$

$\mathrm{Sh}$

$\mathrm{S}_{\mathrm{h}}$

$\mathrm{s}_{\mathrm{i}}$

$\mathrm{t}$ tube surface area of heat exchanger, $\mathrm{m}^{2}$

specific area, $\mathrm{m}^{2} \mathrm{~m}^{-3}$

water activity

wall confinement parameters

Forchheimer drag coefficient (Inertial resistance), $\mathrm{m}^{-1}$

heat capacity of moist air, $\mathrm{J} \mathrm{kg}^{-1}{ }^{\circ} \mathrm{C}^{-1}$

diffusion of water vapor in the air, $\mathrm{m}^{2} \mathrm{~s}^{-1}$

diameter of heat exchanger tube, $\mathrm{m}$

product equivalent diameter, $\mathrm{m}$

total energy, $\mathrm{J}$

relative error, $\%$

mass velocity at minimum flow area of heat exchanger, $\mathrm{kg} \mathrm{m}^{2} \mathrm{~s}^{-1}$

air film mass transfer coefficient, $\mathrm{kg} \mathrm{m}^{-2} \mathrm{~s}^{-1} \mathrm{~Pa}^{-1}$

heat transfer coefficient of heat exchanger, $\mathrm{W} \mathrm{m}^{-2}{ }^{\circ} \mathrm{C}^{-1}$

static enthalpy, $\mathrm{J} \mathrm{kg}^{-1}$

latent heat of water at $0^{\circ} \mathrm{C}, \mathrm{J} \mathrm{kg}^{-1}$

bulk product mass transfer coefficient, $\mathrm{kg} \mathrm{m}^{-2} \mathrm{~s}^{-1} \mathrm{~Pa}^{-1}$

skin mass transfer coefficient, $\mathrm{kg} \mathrm{m}^{-2} \mathrm{~s}^{-1} \mathrm{~Pa}^{-1}$

heat exchanger factors

diffusion flux of species, $\mathrm{kg} \mathrm{m}^{-2} \mathrm{~s}^{-1}$

transpiration rate per unit area of product surface $\mathrm{kg} \mathrm{s}^{-1} \mathrm{~m}^{-2}$

turbulent kinetic energy, $\mathrm{m}^{2} \mathrm{~s}^{-2}$

effective thermal conductivity of porous zone, $\mathrm{W} \mathrm{m}^{-1}{ }^{\circ} \mathrm{C}^{-1}$

empirical constants

pressure, $\mathrm{Pa}$

prandtle number

saturated vapor pressure, $\mathrm{Pa}$

vapor pressure on the surrounding air, $\mathrm{Pa}$

vapor pressure on the product surface, $\mathrm{Pa}$

rate of respiratory heat generation per unit mass of product $\mathrm{J} \mathrm{s}^{-1} \mathrm{~kg}^{-1}$

Reynolds number

gas constant for water vapor, $461.52 \mathrm{~J} \mathrm{~mol}^{-1}{ }^{\circ} \mathrm{K}^{-1}$

relative humidity

Schmidt number

Sherwood number

volumetric heat sources (energy source term), $\mathrm{J} \mathrm{m}^{-3} \mathrm{~s}^{-1}$

momentum source term, $\mathrm{kg} \mathrm{m}^{-2} \mathrm{~s}^{-2}$

time, $s$ 


\begin{tabular}{|c|c|}
\hline $\mathrm{T}$ & temperature, ${ }^{\circ} \mathrm{K}$ \\
\hline $\mathrm{T}_{\mathrm{ave}}$ & overall average of container's temperature, ${ }^{\circ} \mathrm{K}$ \\
\hline $\mathrm{T}_{\mathrm{AVEDEV}}$ & average of the absolute deviations of temperature, ${ }^{\circ} \mathrm{K}$ \\
\hline $\mathrm{T}_{\mathrm{c}}$ & volume average temperature of a container, ${ }^{\circ} \mathrm{K}$ \\
\hline $\mathrm{T}_{\max }$ & temperature of hottest container, ${ }^{\circ} \mathrm{K}$ \\
\hline $\mathrm{T}_{\min }$ & temperature of coolest container, ${ }^{\circ} \mathrm{K}$ \\
\hline $\mathrm{T}_{\mathrm{MD}}$ & maximum deviation of temperature in cool storage, ${ }^{\circ} \mathrm{k}$ \\
\hline $\mathrm{u}$ & velocity, $\mathrm{m} \mathrm{s}^{-1}$ \\
\hline $\mathrm{u}_{\mathrm{m}}$ & measured velocity, $\mathrm{m} \mathrm{s}^{-1}$ \\
\hline $\mathrm{u}_{\mathrm{p}}$ & predicted velocity, $\mathrm{m} \mathrm{s}^{-1}$ \\
\hline $\mathrm{u}_{\mathrm{i}}, \mathrm{u}_{\mathrm{j}}$ & mean velocity components in $\mathrm{X}, \mathrm{Y}$, and $\mathrm{Z}$-directions, $\mathrm{m} \mathrm{s}^{-1}$ \\
\hline $\mathrm{u}_{\mathrm{i}}^{\prime}, \mathrm{u}_{\mathrm{j}}^{\prime}$ & fluctuating velocity components, $\mathrm{m} \mathrm{s}^{-1}$ \\
\hline $\mathrm{u}_{\mathrm{s}}$ & superficial velocity $\mathrm{m} \mathrm{s}^{-1}$ \\
\hline $\mathrm{V}_{\mathrm{p}}$ & average volume of apple, $\mathrm{m}^{3}$ \\
\hline $\mathrm{V}_{\mathrm{h}}$ & volume of heat exchanger, $\mathrm{m}^{3}$ \\
\hline $\mathrm{V}_{\min }$ & air velocity at minimum flow area of heat exchanger unit \\
\hline $\mathrm{x}_{\mathrm{i}} ; \mathrm{x}_{\mathrm{j}}$ & Cartesian coordinates, $\mathrm{m}$ \\
\hline $\mathrm{Y}_{\mathrm{W}}$ & mass fraction of water vapor in the moist air \\
\hline$\alpha$ & Darcy permeability, $\mathrm{m}^{2}$ \\
\hline$\gamma$ & porosity \\
\hline$\delta_{\mathrm{ij}}$ & Kronecker delta \\
\hline$\varepsilon$ & turbulent dissipation rate $\mathrm{m}^{2} \mathrm{~s}^{-3}$ \\
\hline$\mu$ & dynamic viscosity, $\mathrm{kg} \mathrm{m}^{-1} \mathrm{~s}^{-1}$ \\
\hline$\mu_{\mathrm{t}}$ & turbulent viscosity, $\mathrm{kg} \mathrm{m}^{-1} \mathrm{~s}^{-1}$ \\
\hline$\rho_{\text {bulk }}$ & apple bulk density, $\mathrm{kg} \mathrm{m}^{-3}$ \\
\hline$\rho_{\mathrm{ma}}$ & moist air density, $\mathrm{kg} \mathrm{m}^{-3}$ \\
\hline
\end{tabular}

Sub and super-scripts

c cooler( fan and heat exchanger)

f Fan

h heat exchanger

$\mathrm{i}, \mathrm{j} \quad$ Cartesian coordinate index

ma moist air

p product (apple)

sat Saturation 
Table 1. Model parameters

\begin{tabular}{|c|c|}
\hline Parameter & Value \\
\hline Apple mean diameter & $0.059 \mathrm{~m}$ \\
\hline Apple true density & $845.4 \mathrm{~kg} \mathrm{~m}^{-3}$ \\
\hline Apple bulk density & $462.313 \mathrm{~kg} \mathrm{~m}^{-3}$ \\
\hline Apple bulk porosity & 0.4531 \\
\hline Apple moisture content (wet based) & $83.65 \%$ \\
\hline Apple average surface area & $0.0138 \mathrm{~m}^{2}$ \\
\hline Apple specific surface area & $60.43 \mathrm{~m}^{2} \mathrm{~m}^{-3}$ \\
\hline Apple skin mass transfer coefficient & $1.67 \times 10^{-10} \quad \mathrm{~kg} \mathrm{~m}^{-2} \mathrm{~s}^{-1} \mathrm{~Pa}^{-1}$ \\
\hline Apple heat capacity & $3639.275 \mathrm{~J} \mathrm{~kg}^{-1}{ }^{\circ} \mathrm{C}^{-1}$ \\
\hline Apple heat conductivity & $0.560395 \mathrm{~W} \mathrm{~m}^{-1}{ }^{\circ} \mathrm{C}^{-1}$ \\
\hline Moist air density & $1.2893 \mathrm{~kg} \mathrm{~m}^{3}$ \\
\hline Moist air relative humidity & $90 \%$ \\
\hline Moist air heat capacity & $1006.408 \mathrm{~J} \mathrm{~kg}^{-1}{ }^{\circ} \mathrm{C}^{-1}$ \\
\hline Moist air heat conductivity & $0.02397 \mathrm{~J} \mathrm{~kg}^{-1}{ }^{\circ} \mathrm{C}^{-1}$ \\
\hline Moist air viscosity & $1.72 \times 10^{-5} \quad \mathrm{~kg} \mathrm{~m}^{-1} \mathrm{~s}^{-1}$ \\
\hline Water vapor diffusivity in the air & $2.1 \times 10^{-5} \quad \mathrm{~m}^{2} \mathrm{~s}^{-1}$ \\
\hline Latent heat of water (at $0{ }^{\circ} \mathrm{C}$ ) & $2495460 \mathrm{~J} \mathrm{~kg}^{-1}$ \\
\hline HDPE density & $952.5 \mathrm{~kg} \mathrm{~m} 3$ \\
\hline HDPE heat capacity & $2250 \mathrm{~J} \mathrm{~kg}^{-1} \quad{ }^{\circ} \mathrm{C}^{-1}$ \\
\hline HDPE heat conductivity & $0.49 \mathrm{~W} \mathrm{~m}^{-1}{ }^{\circ} \mathrm{C}^{-1}$ \\
\hline Heat exchanger's heat transfer area & $8.81 \mathrm{~m}^{-2}$ \\
\hline Heat exchanger's Heat transfer coefficient & $42 \mathrm{~W} \mathrm{~m}^{-2}{ }^{\circ} \mathrm{C}^{-1}$ \\
\hline $\begin{array}{l}\text { Heat exchanger's average surface } \\
\text { temperature }\end{array}$ & $-2.1{ }^{\circ} \mathrm{C}^{-1}$ \\
\hline
\end{tabular}




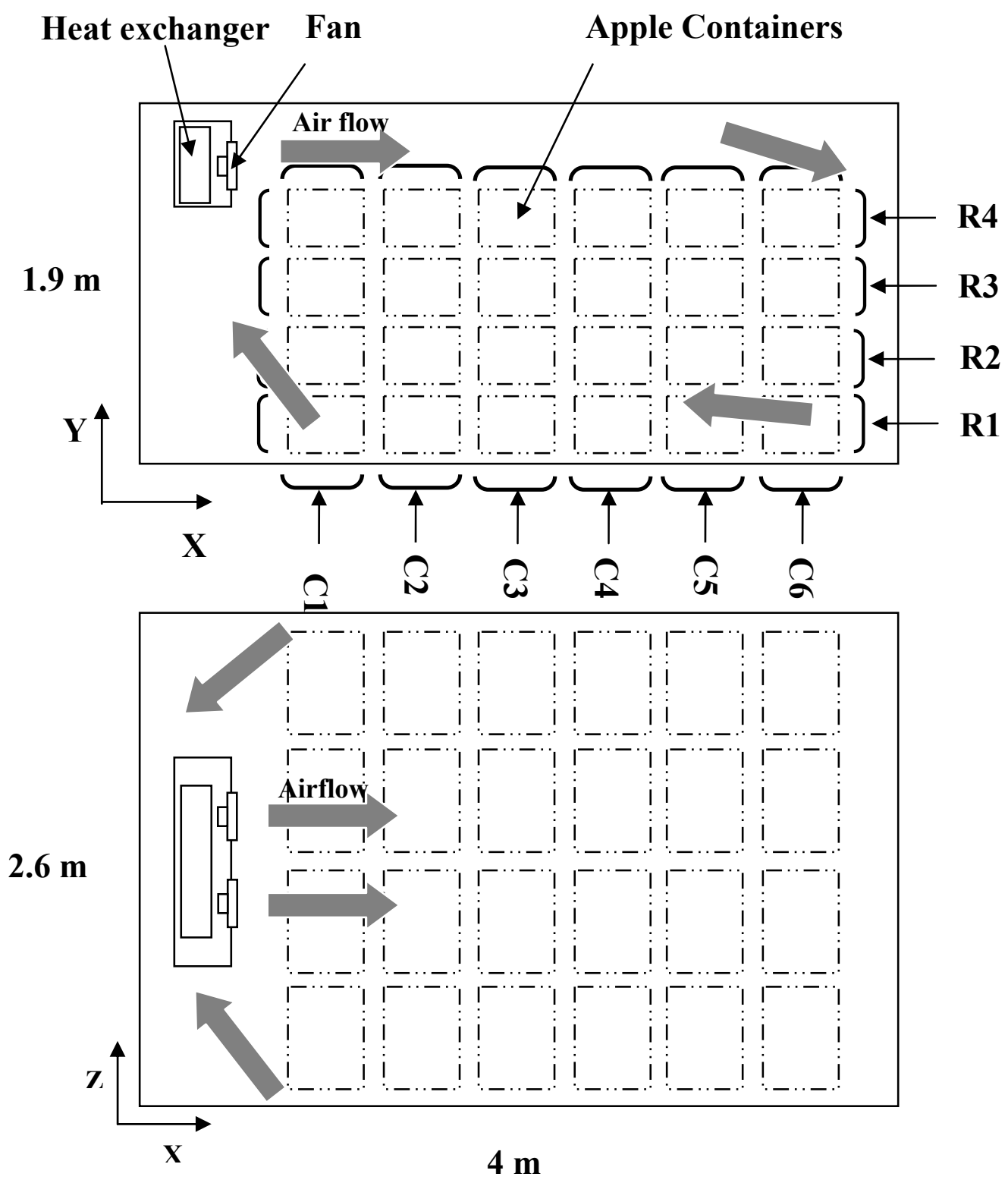

Figure 1. Full loaded cool storage with in-line array of apple vented containers, side view (up), and top view (down) 


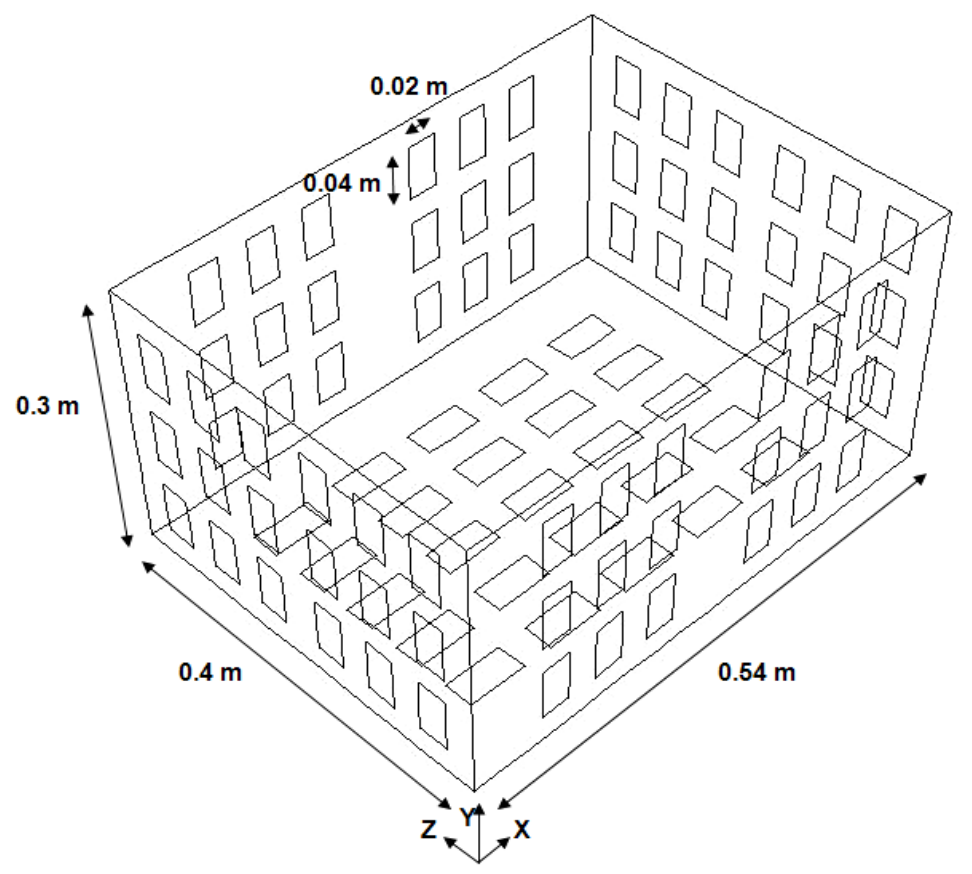

Figure 2. Apple vented container
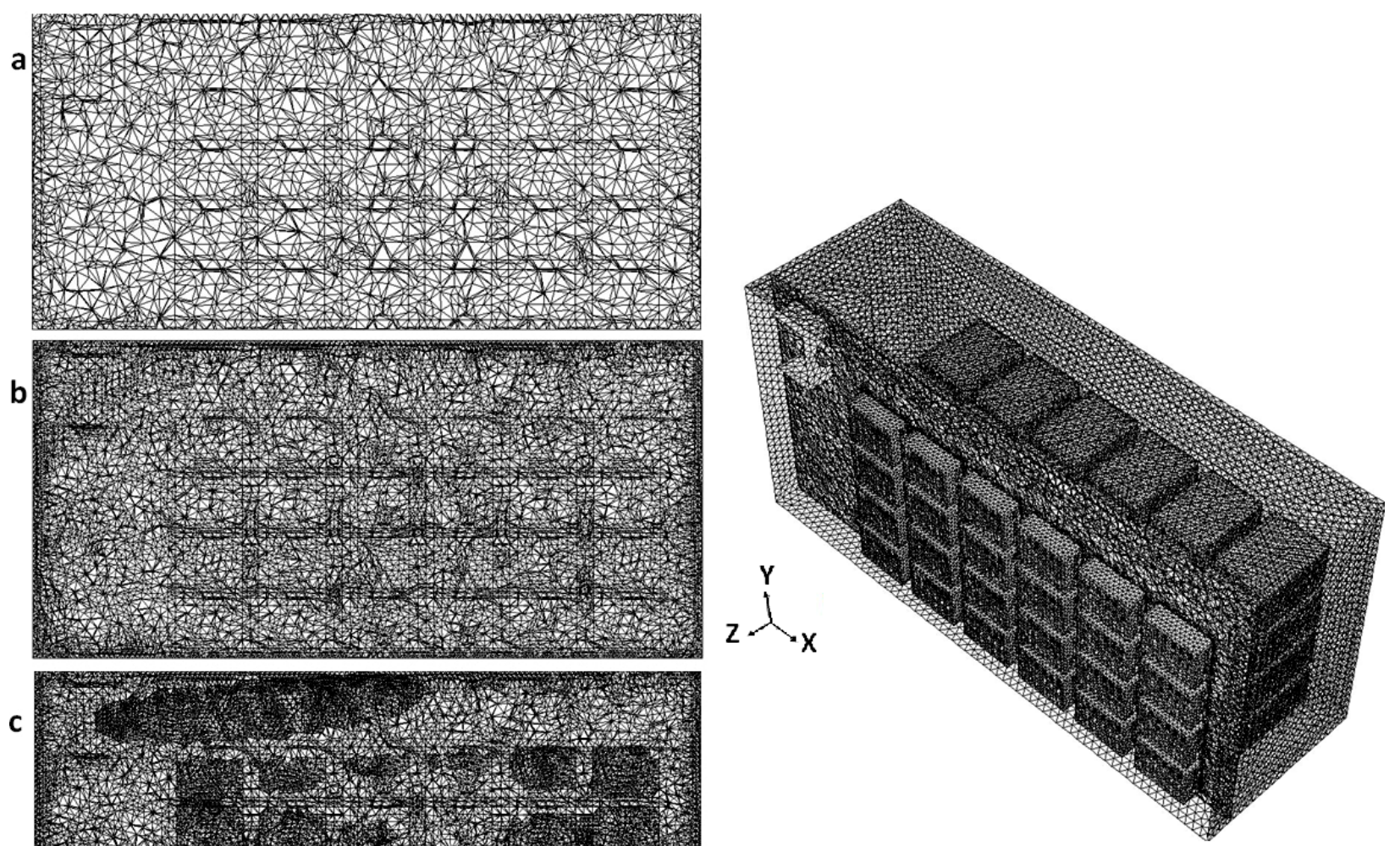

c

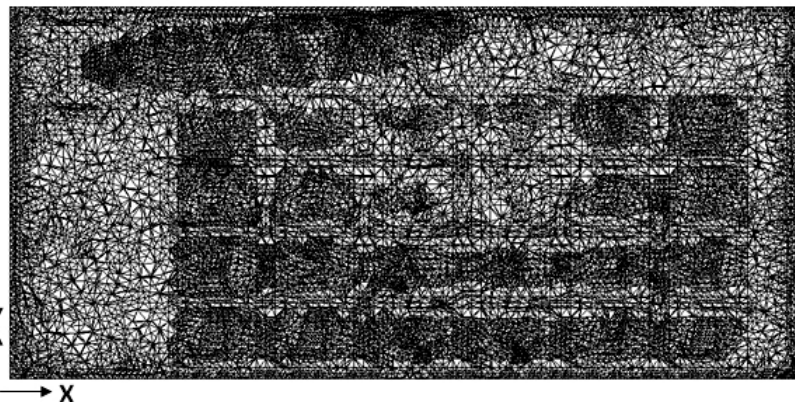

Figure 3. Grid structure of cool storage (right) and grid refinement between the containers wall shown on XY vertical surface crossing the center of fan plan in three steps: $a, b$ and $c$ 


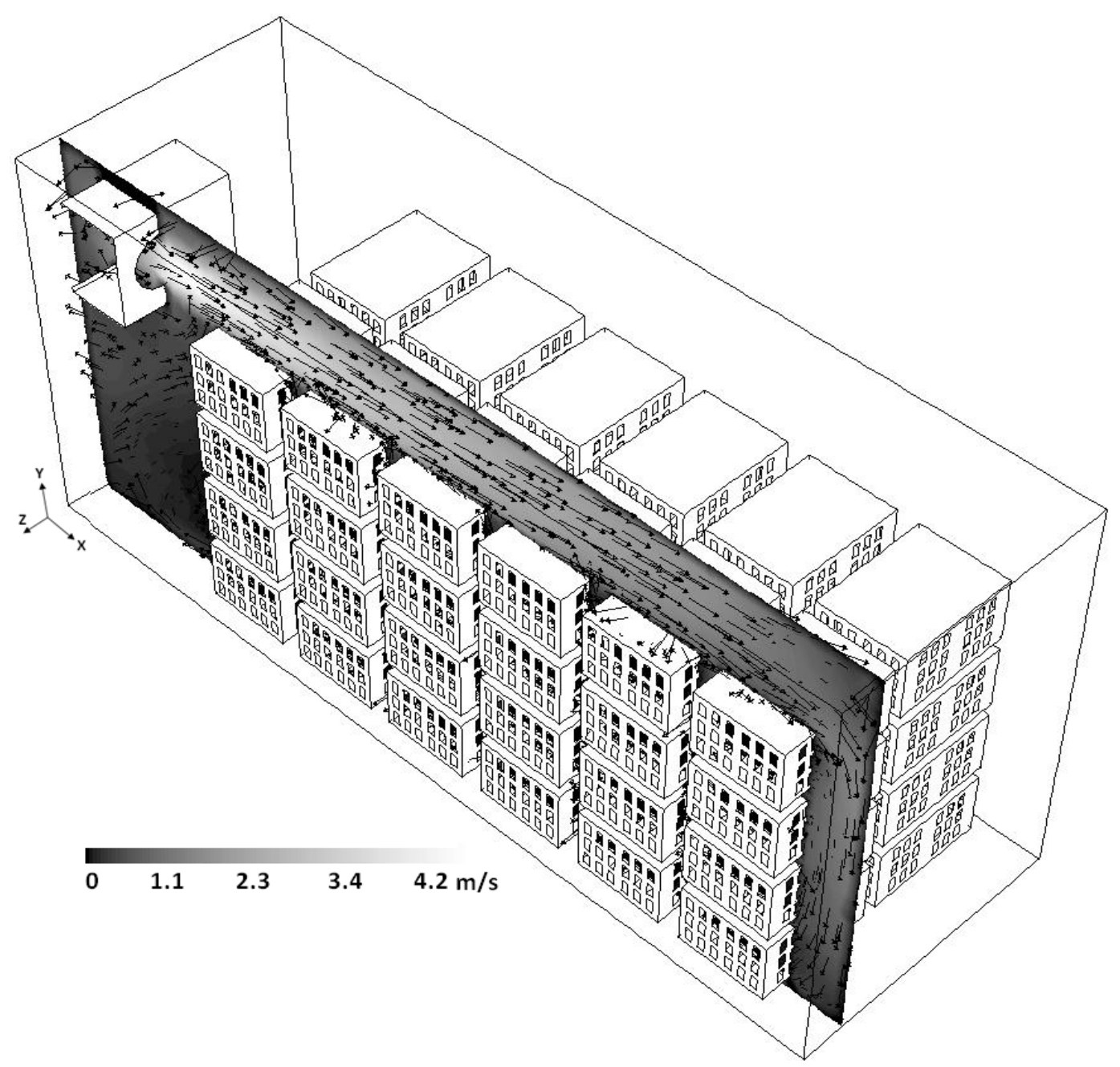

Figure 4. Air velocity fields on XY vertical surface crossing the center of the fan plan inside the cool storage

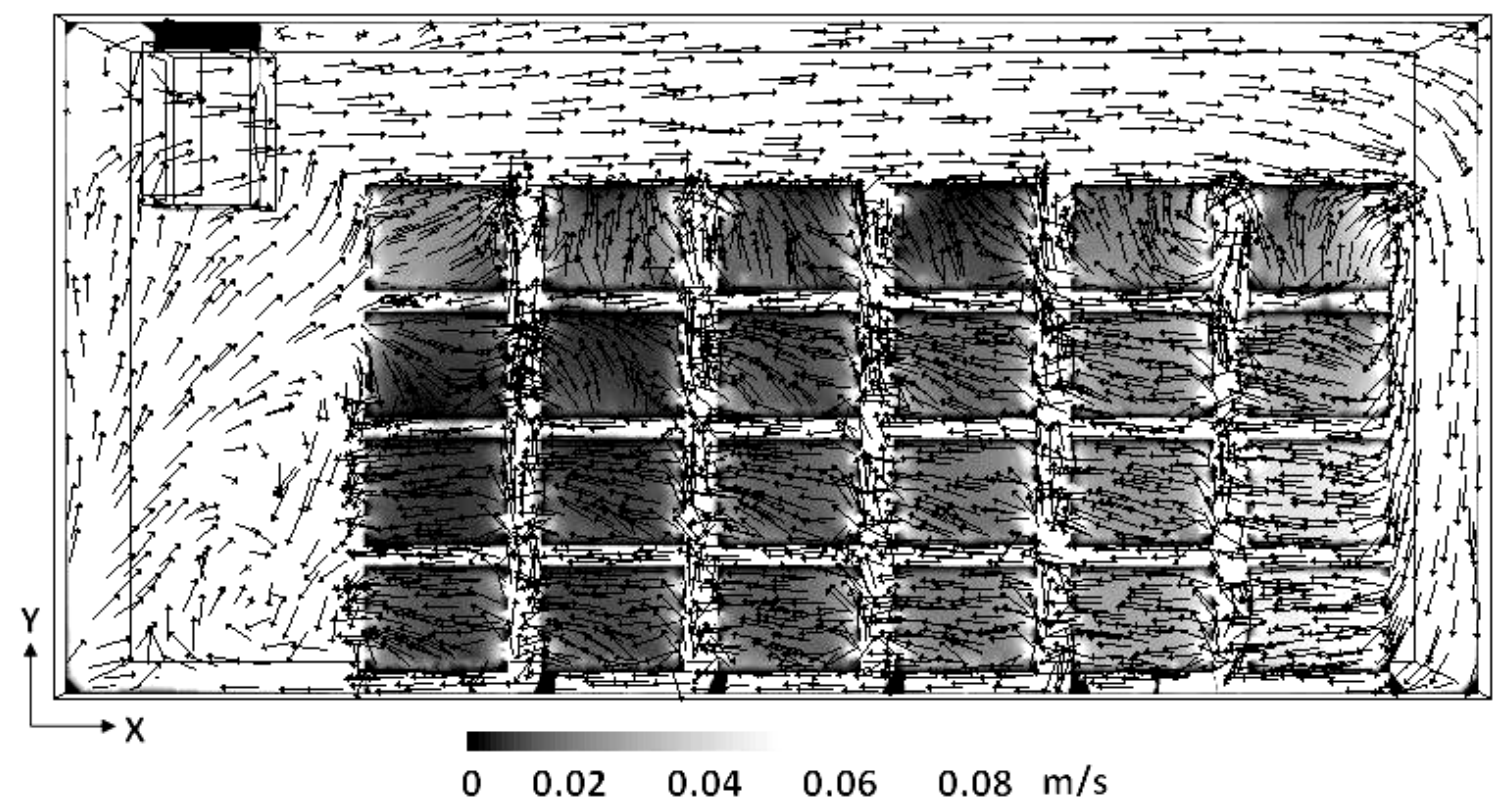

Figure 5. Air velocity contours and vectors inside the containers on XY vertical surface crossing the center of the fan plan inside the cool storage 

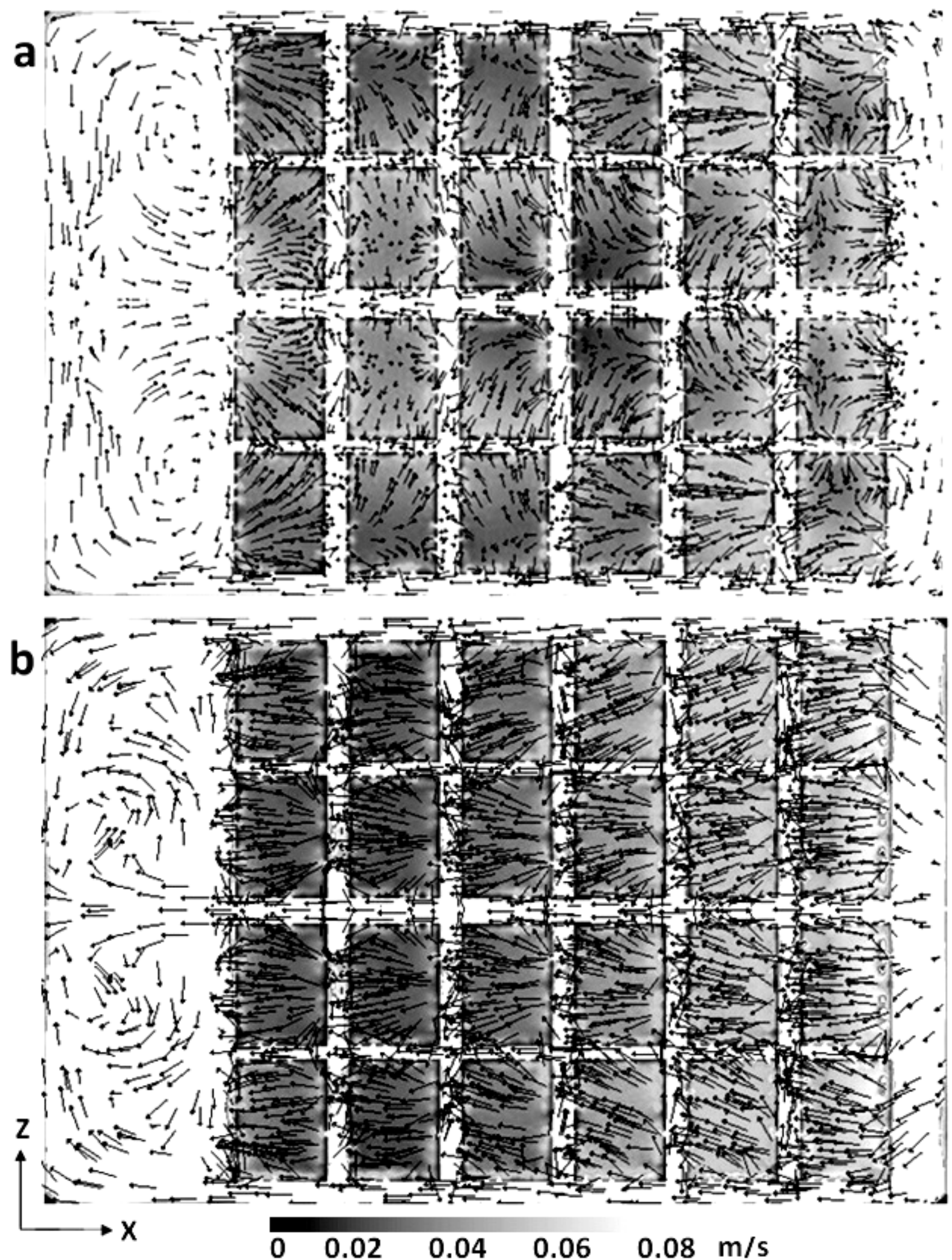

Figure 6. Air velocity contours and vectors on two cross sections crossing the center of the topmost (a), and bottommost (b) containers 

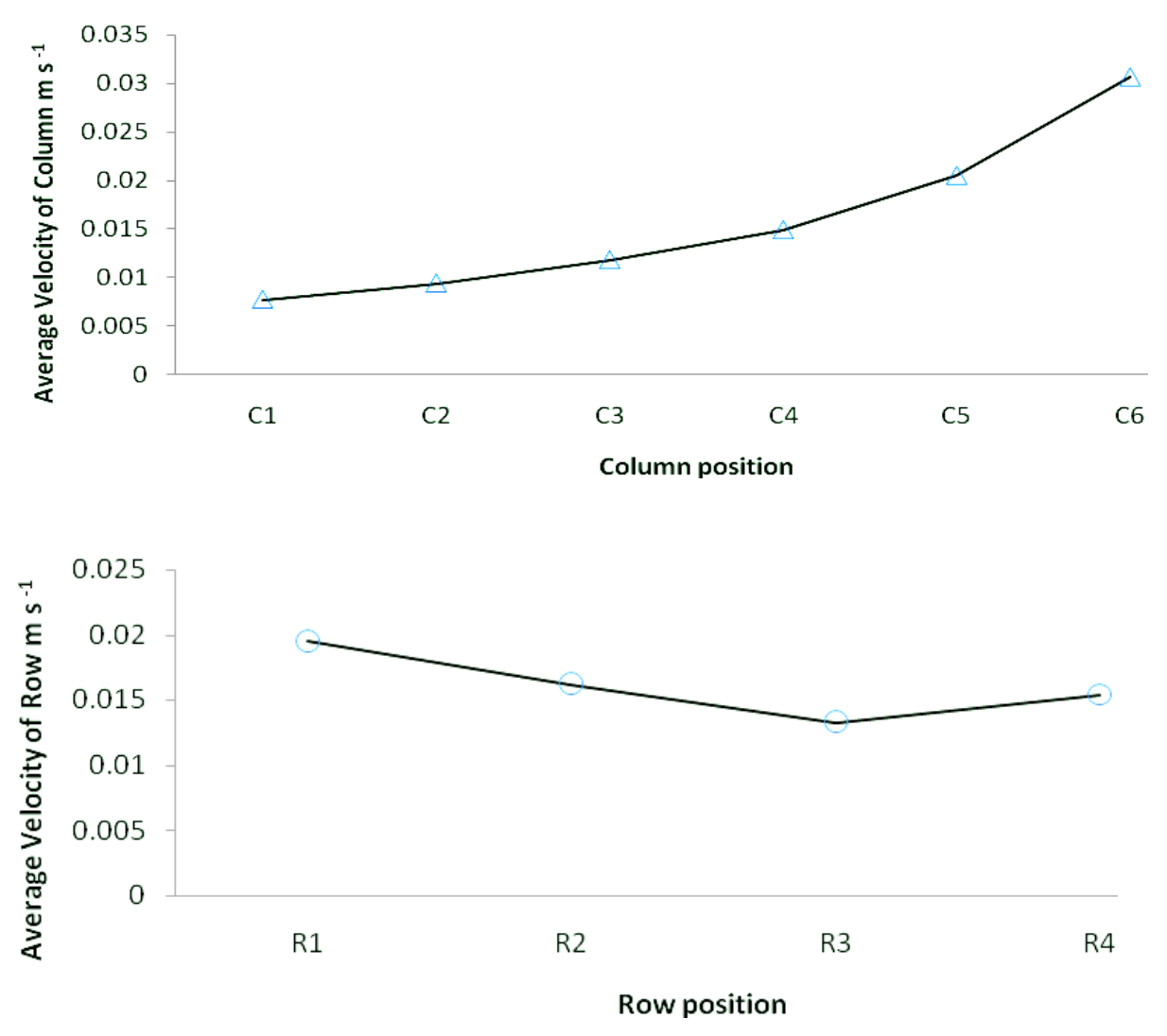

Figure 7. The difference of column (top) and row (down) average velocity inside the containers versus the position of columns/rows

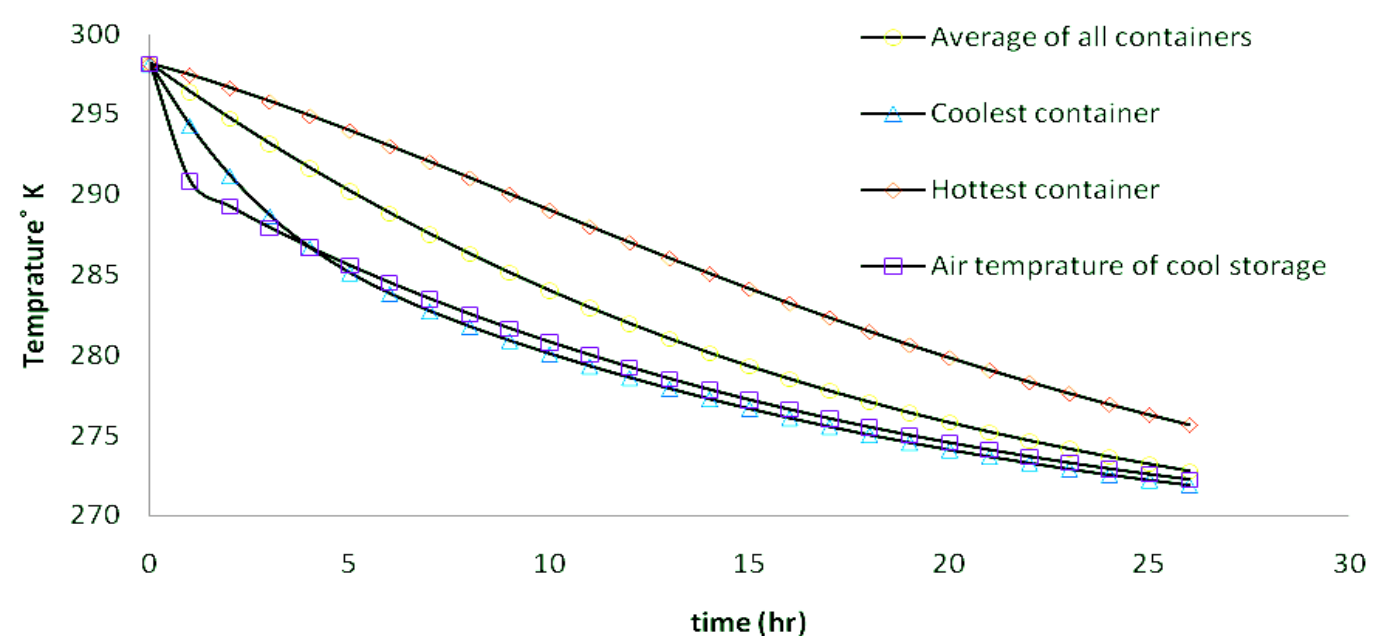

Figure 8. The cooling curve belong to the air, average of all the products, and one of the hottest and coolest containers in cool storage 


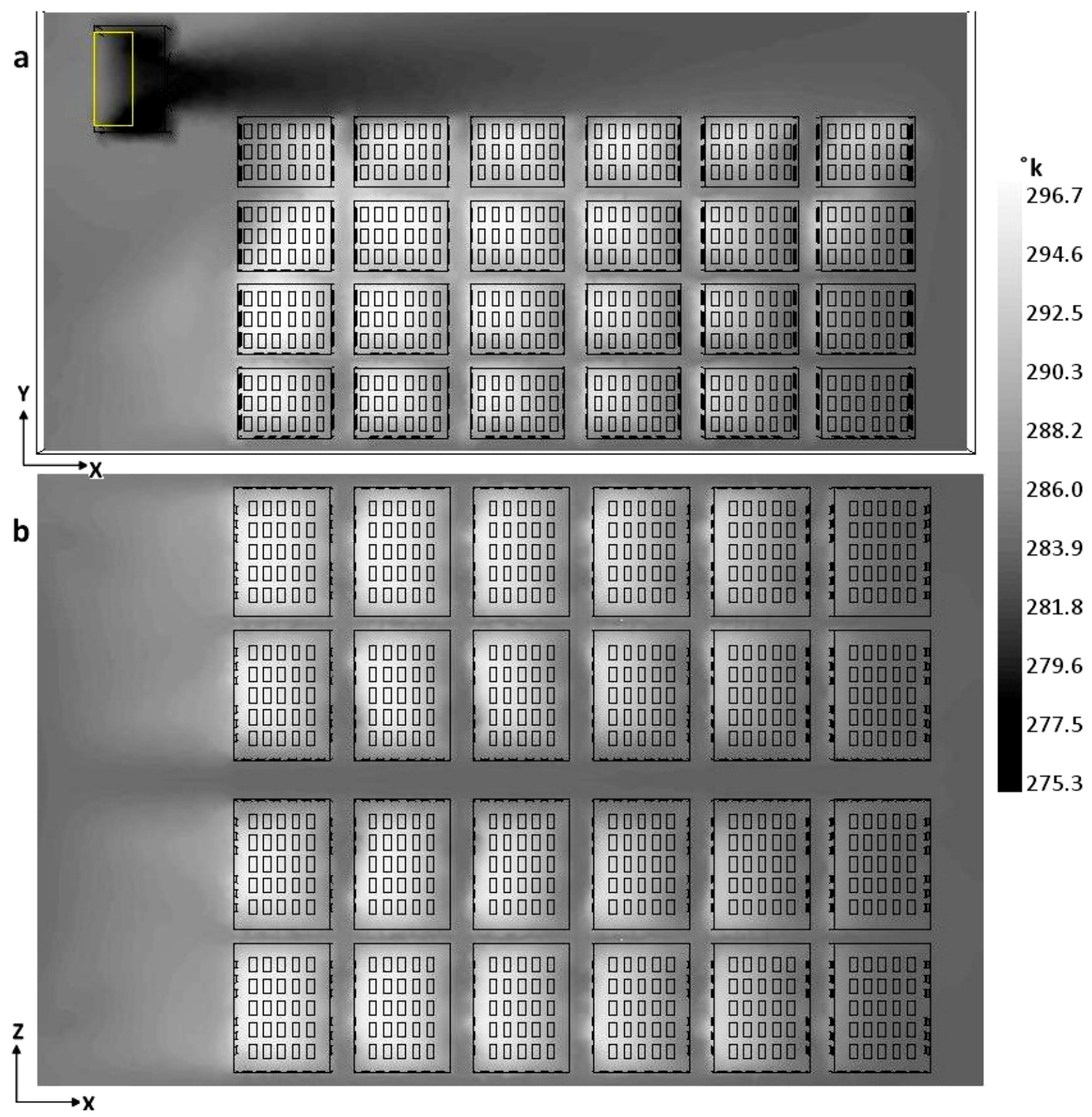

Figure 9. Predicted product temperature after $8.7 \mathrm{hrs}$ of cooling time of initial uniform temperature of $25{ }^{\circ} \mathrm{C}$ at $\mathrm{XY}$ vertical surface crossing the center of fan plan (a), and XZ horizontal surface crossing the center of bottommost containers (b) 


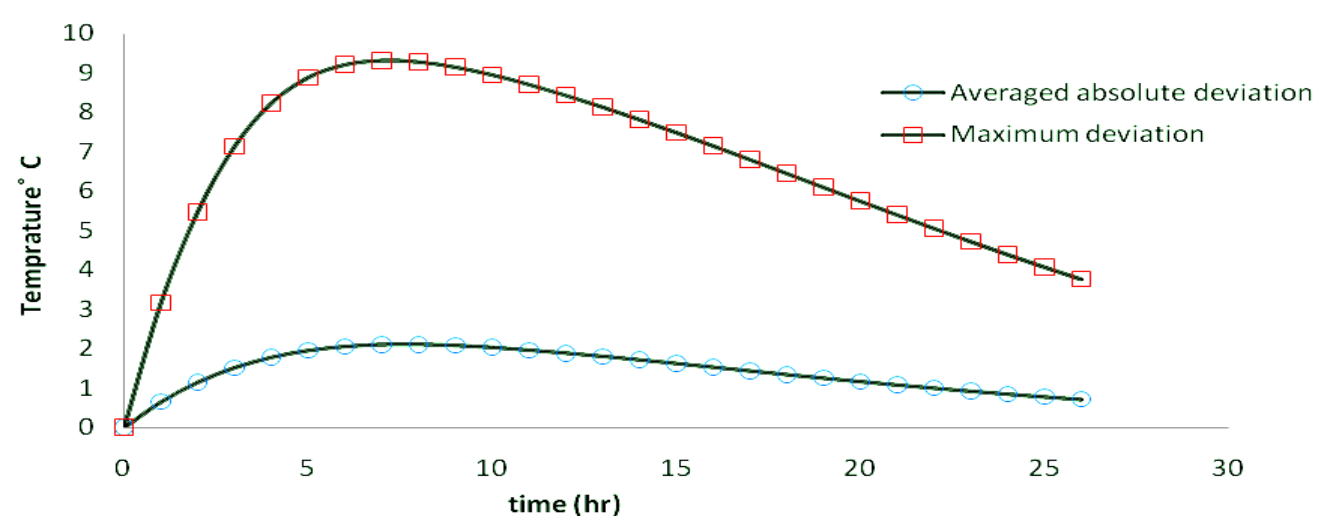

Figure 10. Maximum deviation (the difference between the hottest and coolest product's temperature) and Averaged absolute deviations of product's Temperature during the cooling time
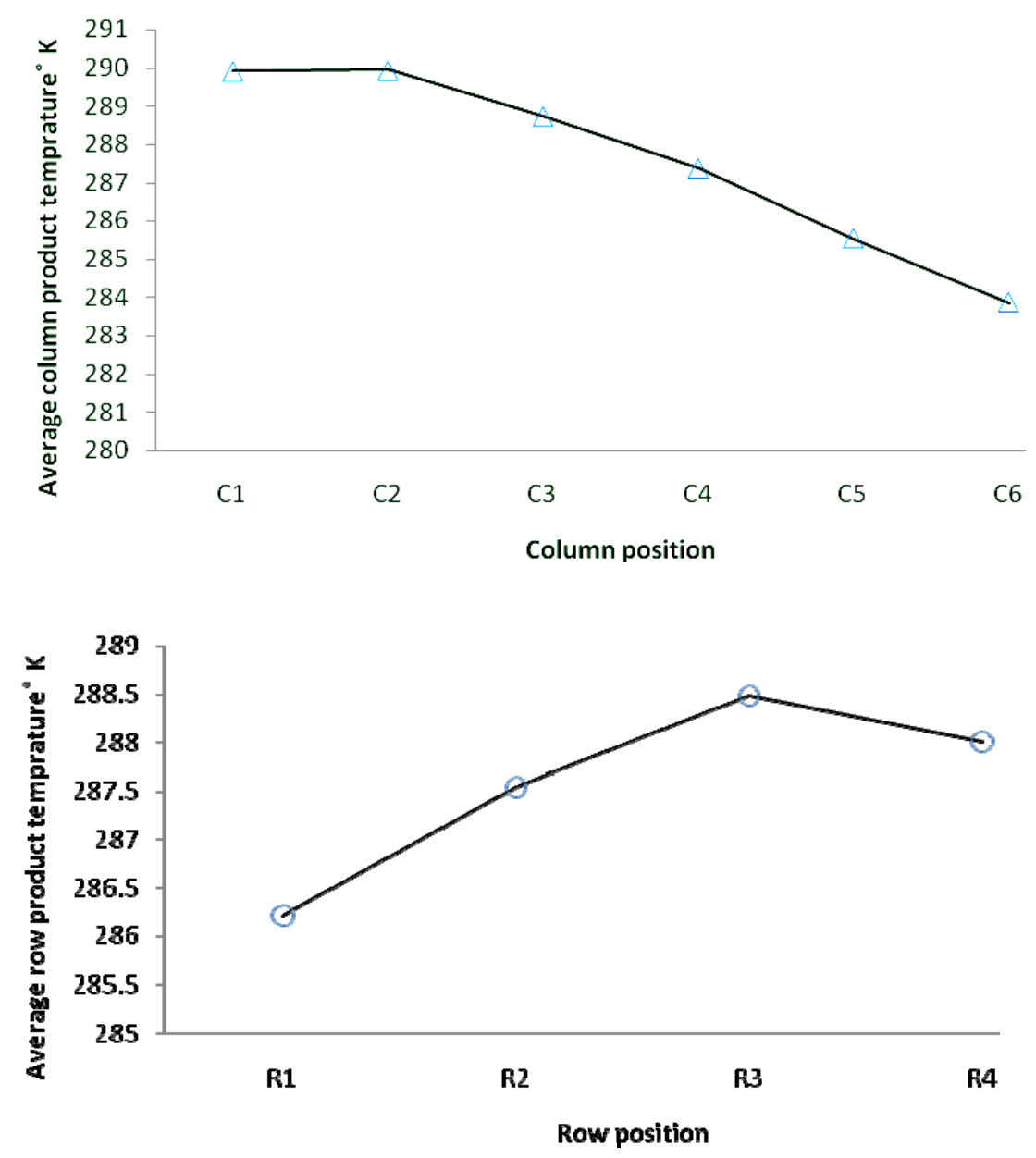

Figure 11. The difference between columns (top) and rows (down) average container temperature versus the position of columns/rows at half-cooling time 